\title{
Cryptosporidiosis in children in a north Jordanian paediatric hospital
}

E.S. Mahgoub, ${ }^{1}$ A. Almahbashi ${ }^{2}$ and B. Abdulatif ${ }^{3}$

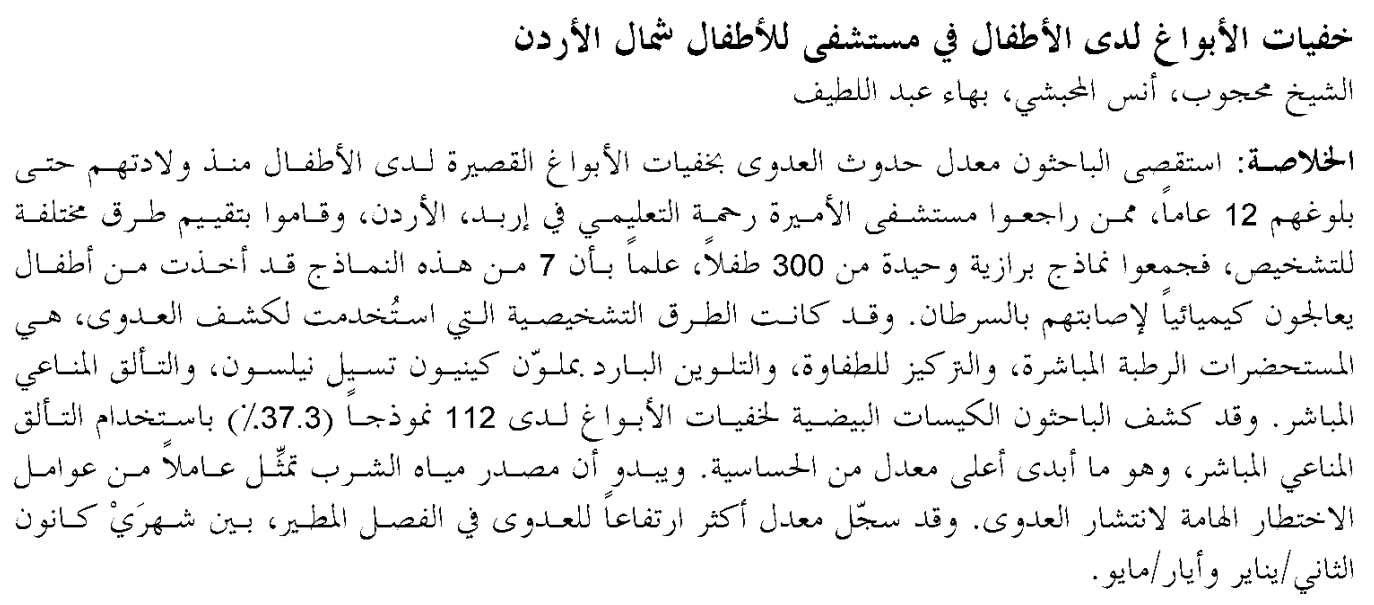

ABSTRACT We investigated the rate of infection by Cryptosporidium parvum among children from birth to 12 years attending Princess Rahma Teaching Hospital in Irbid, Jordan and evaluated various diagnostic methods. We collected single stool specimens from 300 children; 7 specimens were from children undergoing chemotherapy treatment for cancer. Diagnostic methods used for detection of infection were direct wet mount preparation, flotation concentration, cold Kinyoun Ziehl-Neelsen stain and direct immunofluorescence. We detected $C$. parvum oocysts in 112 samples (37.3\%) using direct immunofluorescence, which showed the highest sensitivity. Source of drinking water appeared to be an important risk factor for transmission of infection. A higher incidence of infection was recorded during January-May, the rainy season.

\section{La cryptosporidiose chez l'enfant dans un hôpital pédiatrique du nord de la Jordanie}

RÉSUMÉ Nous avons étudié le taux d'infection par Cryptosporidium parvum chez des enfants de la naissance à l'âge de 12 ans consultant à l'hôpital universitaire Princesse Rahma d'Irbid (Jordanie) et évalué diverses méthodes diagnostiques. Nous avons recueilli un échantillon unique de selles chez 300 enfants ; 7 échantillons provenaient d'enfants sous chimiothérapie anticancéreuse. Les méthodes de diagnostic utilisées pour le dépistage de l'infection était l'examen direct de préparation à l'état frais, la concentration par flottation, la coloration de Ziehl-Neelsen, la coloration de Kinyoun à froid et l'immunofluorescence directe. Nous avons détecté des oocystes de $C$. parvum dans 112 échantillons $(37,3 \%)$ par immunofluorescence directe, méthode qui a montré la plus forte sensibilité. La source d'eau de boisson semblait être un important facteur de risque de transmission de l'infection. Une incidence plus élevée de l'infection a été enregistrée entre janvier et mai, la saison des pluies.

${ }^{1}$ Department of Microbiology, Faculty of Medicine; ${ }^{2}$ Faculty of Applied Medical Science; ${ }^{3}$ Faculty of Veterinary Science, Jordan University of Science and Technology, Irbid, Jordan.

Received: 27/10/02; accepted: 14/09/03

الجلة الصحية لشرق المتوسط، منظمة الصحة العالمية، المجلد العاشر، العددان ع-0، ع • • 


\section{Introduction}

Cryptosporidium parvum is a coccidian protozoan parasite found in the brushborder of the enterocytes of the small intestine in many vertebrates, including humans [1]. Cryptosporidiosis is recognized as a cause of diarrhoeal illness in man and several mammalian species [2]. The first cases of human cryptosporidiosis were reported in 1976, and there are increasing numbers of reports of patients with documented infection with C. parvum. It is now considered a common enteric pathogen in humans and domestic animals worldwide [3]. Cryptosporidiosis can induce self-limiting diarrhoea in immunocompetent people or severe and prolonged diarrhoea in immunocompromised patients, such as those with AIDS, transplant recipients, those receiving chemotherapy for cancer, institutionalized patients, and patients with immunosuppressive infectious disease [4].

A study in the same area of Jordan in 1994 reported that the rate of infection among elementary-school children was 7\% [5].

Diagnosis of the infection generally requires the observation of the infective stage (oocysts 4-6 $\mu \mathrm{m}$ ). Owing to the small size of the oocysts, the routine wet mount preparation and concentration methods have limited value for detection of $C$. parvum in faecal samples, where oocysts can easily be confused with other materials present in the sample [6].

We conducted this study because of the increasing international documentation of infection by C. parvum and the fact that it is under-diagnosed in most Jordanian hospital laboratories. We also wanted to compare the different methods used for the diagnosis of $C$. parvum including the direct immunofluorescence test which was used for the first time in Jordan in this study. In addition, we tried to focus on some epidemiological factors that lead to infection in children.

\section{Methods}

\section{Patients}

Over a period of 11 months, 300 single stool specimens were collected from children attending outpatient clinics as well as inpatients in Princess Rahma Teaching Hospital. Requests for stool examinations were made by paediatricians who deemed it necessary for diagnosis and follow-up of their patients. Princess Rahma Teaching Hospital is the hospital for medical care of children under 12 years of age. Faecal samples were taken from children with diarrhoea who were sent to the laboratory for investigation. Seven of the children were undergoing chemotherapy for cancer. There were no exclusion criteria.

The purpose of the study was verbally explained to the parents who agreed to give samples from their children. Paeditricians filled in the clinical information and supplied data on drugs as well as chemotherapeutic agents used for treatment. Additional information about the children was obtained by means of a questionnaire filled in with the assistance of the parents. Information requested included name, age, sex and residence (urban/rural). The source of drinking water was also ascertained (well, spring, tap, filtered, boiled). Parents were also asked whether they kept animals in the home.

\section{Laboratory tests}

Stool specimens were collected in the laboratory facilities at Princess Rahma Teaching Hospital and transported in a cool box to the laboratory in the Department of Microbiology at Jordan University of Science

المحلة الصحية لشرق المتو سط، منظمة الصحة العالمية، المحلد العاشر، العلددان ع-0، ع • • 
and Technology in Irbid. Each sample, whether liquid, semi-solid or formed, was divided in 4 aliquots and processed according to each of the 4 methods described here. In all methods used, a positive slide was read by at least 2 of the investigators.

\section{Direct wet mount}

The direct wet mount preparation was used according to the World Health Organization Bench aids for the diagnosis of intestinal parasites [7]. Lugol's 1\% iodine was used to differentiate C. parvum oocysts from yeast cells: C. parvum oocysts do not accept the iodine stain, so they appear transparent; yeast cells accept the stain and appear deep yellow.

\section{Sugar flotation concentration method}

Sheather's sugar flotation technique was used (specific gravity of solution 1.20 1.25). The high specific gravity allows the oocysts to float on the top of the solution in the test tube. Briefly, a suspension of stool in sugar solution was made in a test tube filled to the brim with Sheather's sugar solution. A cover slip was put on top of the test tube in contact with the solution for 15 minutes. The cover slip was placed downwards on a microscope slide and the oocysts were visualized microscopically at $\times 400$ magnification $[8,9]$.

\section{Cold Kinyoun staining}

Differential staining using a modified ZiehlNeelsen technique, the cold Kinyoun technique (TCS Biosciences Limited, Buckingham, United Kingdon), was employed to differentiate $C$. parvum oocysts from other cells and artefacts. The oocysts are acid-fast so they accept the stain and appear pink to red in colour (4-6 mm) against a blue background of debris.

\section{Direct immunofluorescent antibody}

staining

MeriFluor ${ }^{\mathrm{TM}}$ Cryptosporidium/Giardia (Meridian Diagnostic Incorporated, Cincinnati, United States of America) is an in vitro direct immunofluorescence kit for the simultaneous detection of Cryptosporidium oocysts and Giardia cysts in faecal material. The detection reagent contains a mixture of fluorescein isothiocynate-labelled monoclonal antibodies directed against cell wall antigens of Cryptosporidium oocysts. Positive and negative controls were provided with the kit by the manufacturing company and manufacturer's instructions were followed.

\section{Statistical analysis}

Statistical analysis was performed using SPSS.

\section{Results}

Of 300 stool samples, 112 (37.3\%) were positive for $C$. parvum. According to the consistency of the sample, oocysts were detected in $27.2 \%$ of liquid samples, $51.1 \%$ of semi-solid samples and $12.5 \%$ of formed samples. Among the 7 children who were on chemotherapy for cancer, $C$. parvum was detected in the stools of 4 (57.1\%).

The monoclonal direct immunofluorescence method gave the highest rate of positive samples (37.3\%) (Table 1) and was statistically the most sensitive compared with the other 3 methods (Table 2). In addition, under ultraviolet light, the direct immunofluorescence slide showed clear, oval, fluorescent green oocysts against an orange to dark background.

When the results were examined according to the children's age, the highest 
Table 1 Comparison of four methods for diagnosis of Cryptosporidium parvum

\begin{tabular}{|c|c|c|}
\hline \multirow[t]{2}{*}{ Method } & \multicolumn{2}{|c|}{$\begin{array}{c}\text { Samples positive, } \\
n=300\end{array}$} \\
\hline & No. & $\%$ \\
\hline Direct wet mount & 52 & 17.3 \\
\hline Sheather's flotation & 68 & 22.6 \\
\hline Cold Kinyoun stain & 92 & 30.6 \\
\hline Direct immunofluorescence & 112 & 37.3 \\
\hline
\end{tabular}

rate of infection (57\%) was noted among those in the age group $5-<7$ years (Figure 1).

The relation of infection to locality, sex, presence of animals in the home and source of drinking water is illustrated in Table 3. There was no significant difference in the distribution of cases between males and females. Out of 138 samples from children who lived in rural areas, 60 (43.5\%) were positive for $C$. parvum oocysts, whereas of the 162 samples from children who lived in urban areas only 52 (32.1\%) were positive. In regard to the presence of animals, the infection rate was $36.2 \%$ among children who lived in compounds with no ani- mals in comparison with $45.0 \%$ among those who lived in association with animals. In the children who drank tap water, the infection rate was $35.3 \%$. In those who drank well water or spring water, however, infection rates were $48.4 \%$ and $42.9 \%$ respectively.

The seasonal pattern of $C$. parvum infection showed that a higher rate of incidence was recorded in the periods from January to July 2001, the first 5 months of which represent the rainy months for that year (Figure 2).

Table 2 shows the comparative results between the 4 methods usually used for diagnosis of C.parvum in stools. Comparison of the various methods revealed the superiority of immunofluorescence followed by the modified Ziehl-Neelsen, sugar flotation and the direct methods.

\section{Discussion}

Our findings showed a high incidence of cryptosporidiosis in the 300 children whose stools we examined. Oocysts of $C$. parvum were detected in $37.3 \%$ of samples using the immunofluorescence technique. This is the first time the immunofluores-

\begin{tabular}{|c|c|c|c|}
\hline Method & $\begin{array}{c}\text { Specificity } \\
\text { (\%) }\end{array}$ & $\begin{array}{c}\text { Sensitivity } \\
\text { (\%) }\end{array}$ & $\begin{array}{l}\text { Efficiency } \\
\text { (\%) }\end{array}$ \\
\hline Direct wet mount & 95 & 47 & 81 \\
\hline Sheather's flotation & 96 & 61 & 85 \\
\hline Cold Kinyoun stain & 100 & 82 & 94 \\
\hline $\begin{array}{l}\text { Direct } \\
\text { immunofluorescence }\end{array}$ & 100 & 98 & 99 \\
\hline
\end{tabular}

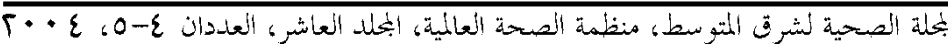




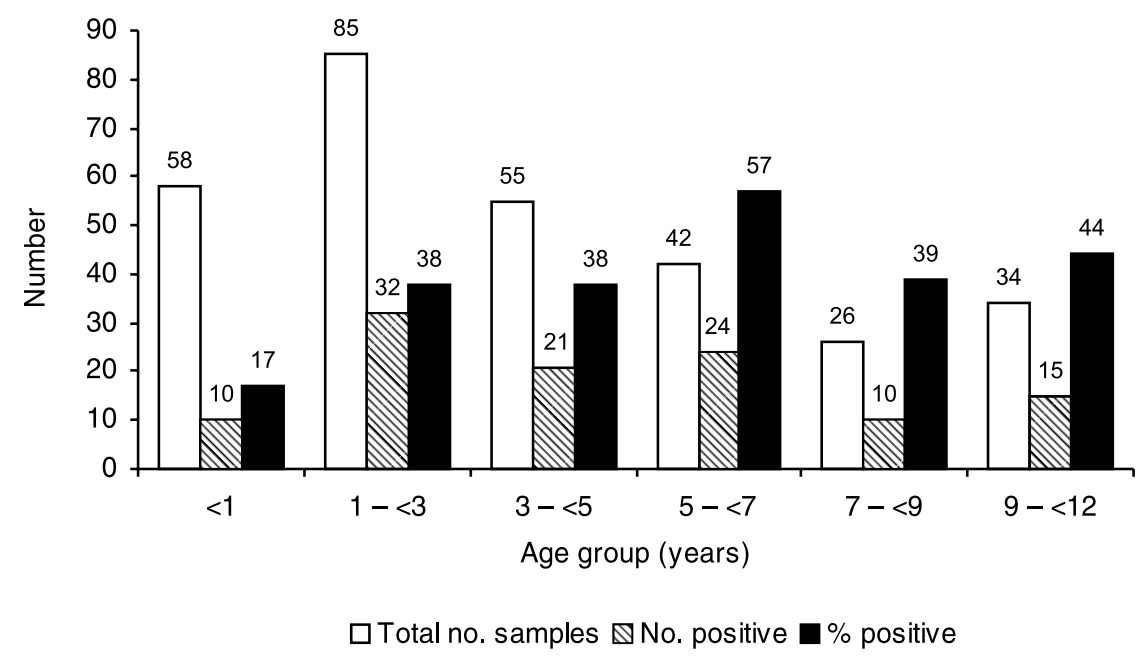

Figure 1 Incidence of cryptosporidiosis according to age

\begin{tabular}{|c|c|c|}
\hline \multicolumn{3}{|c|}{$\begin{array}{l}\text { Table } 3 \text { The rate of infection by } \\
\text { Cryptosporidium parvum in relation to } \\
\text { sociodemographic characteristics and } \\
\text { source of drinking water }\end{array}$} \\
\hline \multirow[t]{2}{*}{ Variable } & \multicolumn{2}{|c|}{ Positive } \\
\hline & No. & $\%$ \\
\hline \multicolumn{3}{|l|}{ Sex } \\
\hline Male & $72 / 186$ & 38.7 \\
\hline Female & $40 / 114$ & 35.1 \\
\hline \multicolumn{3}{|l|}{ Locality ${ }^{b}$} \\
\hline Rural & $60 / 138$ & 43.5 \\
\hline Urban & $52 / 162$ & 32.1 \\
\hline \multicolumn{3}{|c|}{ Animals at residence ${ }^{c}$} \\
\hline With & $18 / 40$ & 45.0 \\
\hline Without & $94 / 206$ & 36.2 \\
\hline \multicolumn{3}{|c|}{ Source of drinking water } \\
\hline Well water & $31 / 64$ & 48.4 \\
\hline Spring water & $3 / 7$ & 42.9 \\
\hline Tap water & $73 / 207$ & 35.3 \\
\hline Filtered water & $4 / 14$ & 28.6 \\
\hline Boiled water & $0 / 7$ & - \\
\hline
\end{tabular}

aP $=0.529$, degrees of freedom $=1, \chi^{2}=0.40$.

${ }^{b} \mathrm{P}=0.042$, degrees of freedom $=1, \chi^{2}=4.12$.

$c \mathrm{P}=0.282$, degrees of freedom $=1, \chi^{2}=1.16$.

${ }^{d P}=0.425$, degrees of freedom $=3, \chi^{2}=1.71$. cence test has been used in Jordan. Although this figure is higher than the one reported before from Jordan [10], it is similar to high figures from other countries as cited below. It is also worth noting that previous workers from Jordan took specimens from healthy schoolchildren while ours were sick children reporting to a paediatric hospital. Our colleagues used a single method, namely the modified ZiehlNeelsen, while we used 4 methods.

A number of other studies on prevalence of cryptosporidiosis have been reported from different parts of the world. The incidence rates vary according to sample collection, which depends on clinical judgement; diagnostic tests, where some methods are better than others; availability of facilities; and reporting systems. Incidence rates of $13.5 \%$ to $19.5 \%$ have been reported from Egypt [11,12], and $10 \%$ in Kuwaiti children [13]. Very high rates have been reported in Israeli children 48\% [14], from the Texas-Mexico border 70.2\% [15] and from the Republic of Korea 57\% [16].

بلملة الصحية لشرق المتوسط، منظمة الصحة العالمية، البجلد العاشر، العددان ع-0، ع • •؟ 


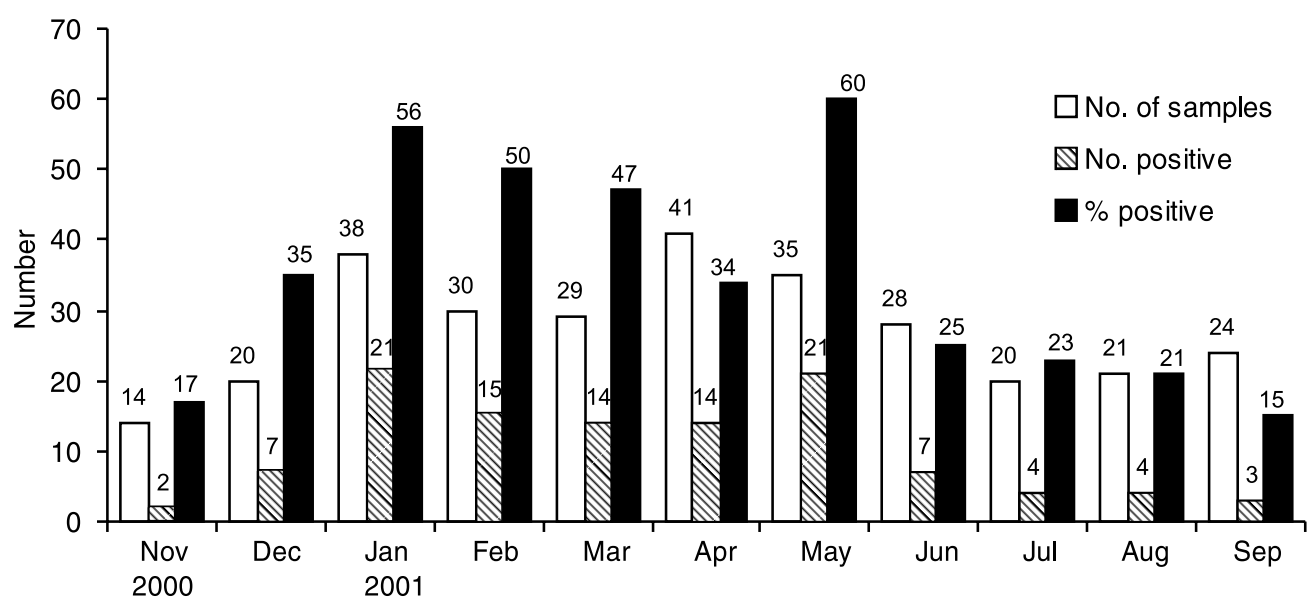

Figure 2 Seasonal variation of cryptosporidiosis, November 2000 to September 2001

A review of several human populationbased studies, especially on immunocompromised patients in less-developed countries, reported prevalence ranging from $9 \%$ to $48 \%$ in Africa and Asia [17].

In this study, 4 different methods were used to detect and identify C. parvum oocysts in children's stool samples. The direct wet mount with iodine identified the lowest number of samples, 52 (17.3\%), positive for oocysts. The $C$. parvum oocyst is very small in size and can easily be mistaken in stool debris for artefacts. Also, it is easy to confuse with other oocysts, such as those of Cyclospora spp., and cells, especially yeast cells, which resemble C. parvum oocysts in size and morphology [18].

The number of oocysts detected increased to 68 (22.6\%) using the flotation concentration method. This procedure showed a clear slide picture during microscopic examination yet the oocysts did not appear pink and refractile, and other para- sites cannot be detected by this method. Also, this procedure necessitated reading the results within 15 minutes of preparation because the oocysts tend to collapse and disappear if left for a long time. Moreover, the presence of Sheather's sugar solution inhibits the staining procedure [19].

The cold Kinyoun acid-fast staining technique yielded a higher rate of oocyst identification, 92 (30.6\%). Using this method we could differentiate between $C$. parvum oocysts, which take a red to pink colour, and other faecal components, especially yeast cells, which take the colour of the counterstain, i.e. blue if using methylene blue, or green using malachite green.

The direct immunofluorescence method gave the highest number of positive samples, 112 (37.3\%). In comparison with other methods, this method showed high sensitivity so we were able to detect oocysts even when present in low numbers in the samples and large numbers of samples could be scanned.

بلملة الصحية لشرةق المثو سط، منظمة الصحة العالمية، البحلد العاشر، العلدان ع-0، ع • • 
Our findings support and agree with other studies which reported that using fluorescent monoclonal reagents increased the sensitivity and specificity of the detection of $C$. parvum oocysts. It provides an excellent screening method and offers a useful technique for epidemiological studies, and hence, control of the parasite [2022]

Source of drinking water plays an important role in the transmission of infection. Many people in Irbid depend on untreated rainwater collected directly from the roof, then stored in metal or cement tanks. This is why most of our cases were diagnosed during April-May, during the rainy season. Some families use wells or spring water for drinking. The results showed that the rate of infection among those who drink from wells was $48.4 \%$, compared to those who use only tap water, $35.3 \%$. We know that the oocysts of Cryptosporidium spp. can survive in concentrations of chlorine used for water treatment, let alone untreated water [23].
Considering the locality, we found that the infection rate in children who lived in rural areas was $43.5 \%$ whereas in children in urban areas it was $32 \%$.

Seasonal or temporal trends associated with increased incidence vary from country to country. Our result agrees with other studies from Central America, South Afri$\mathrm{ca}$, and India that reported a high peak incidence in rainy season [24]. Also, our findings were similar to those of another study conducted in Kuwait to detect the incidence and seasonality of cryptosporidiosis in Kuwaiti children. The results of that study showed that the maximum numbers of cases were recorded during the months January to April [13].

\section{Acknowledgement}

This study was supported by the Deanship of Research, Jordan University of Science and Technology.

\section{References}

1. Tzipori S. Cryptosporidiosis in animals and humans. Microbiological reviews, 1983, 47(1):84-96.

2. Fayer R, Ungar BL. Cryptosporidium spp. and cryptosporidiosis. Microbiological reviews, 1986, 50(4):458-83.

3. Meisel $\mathrm{JL}$ et al. Overwhelming watery diarrhea associated with a cryptosporidium in an immunosuppressed patient. Gastroenterology, 1976, 70(6):1156-60.

4. Fayer R, Morgan U, Upton SJ. Epidemiology of Cryptosporidium: transmission, detection and identification. International journal for parasitology, 2000, 30(12-13):1305-22.

5. Nemri LF and Hijazi SS. Cryptosporidium a cause of gastroenteritis in pre- school children in Jordan. Journal of clinical gastroenterology, 1994, 19(4): 288-91.

6. Weber $\mathrm{R}$ et al. Threshold of detection of Cryptosporidium oocysts in human stool specimens: evidence for low sensitivity of current diagnostic methods. Journal of clinical microbiology, 1991, 29(7): 1323-7.

7. O‘Donoghue JP. Cryptosporidium and cryptosporidiosis in man and animals. International journal for parasitology, 1995, 25(2):139-95.

8. Bench aids for the diagnosis of intestinal parasites. Geneva, World Health Organization, 1994.

البحلة الصحية لشرق المثتوسط، منظمة الصحة العالمية، البحلد العاشر، العددان ع-0، ع • • 
9. Garcia LS. Practical guide to diagnostic parasitology. Washington DC, ASM Press, 1999.

10. Nimri LF, Batchoun R. Prevalence of Cryptosporidium species in elementary school children. Journal of clinical microbiology, 1994, 32(4):1040-2.

11. Stazzone AM et al. Frequency of Giardia and Cryptosporidium infections in Egyptian children as determined by conventional and immunofluorescence methods. Pediatric infectious disease journal, 1996, 15(11):1044-6.

12. Abdel-Maboud Al et al. Cryptosporidiosis in Benha; study of some modalities in diagnosis and treatment. Journal of the Egyptian Society of Parasitology, 2000, 30(3):717-25.

13. Iqbal $\mathrm{J}$ et al. Cryptosporidiosis in Kuwaiti children: seasonality and endemicity. Clinical microbiology and infection, 2001, 7(5):261-6.

14. Robin $\mathrm{G}$ et al. Cryptosporidium infection in Bedouin infants assessed by prospective evaluation of anticryptosporidial antibodies and stool examination. American journal of epidemiology, 2001, 153(2):194-201.

15. Leach CT et al. Prevalence of Cryptosporidium parvum infection in children along the Texas-Mexico border and associated risk factors. American journal of tropical medicine and hygiene, 2000, 62(5):656-1.

16. Cha JY et al. High prevalence and seasonality of cryptosporidiosis in a small rural village occupied predominantly by aged people in the Republic of Korea. American journal of tropical medicine and hygiene, 2001, 65:518-22.

17. Ungar BLP. Cryptosporidium. In: Mandell GL, Bennett JE, Dolin R, eds. Mandell,
Douglas and Bennett's principles and practice of infectious diseases, 5th ed. Philadelphia, Churchill Livingstone, 1999:2903-15.

18. Fayer R, Speer SA, Dubey JP. The general biology of Cryptosporidium. In: Fayer $\mathrm{R}$, ed. Cryptosporidium and cryptosporidiosis. Boca Raton, Florida, CRC Press, 1997:1-41.

19. Weber $\mathrm{R}$ et al. Threshold of detection of Cryptosporidium oocysts in human stool specimens: evidence for low sensitivity of current diagnostic methods. Journal of clinical microbiology, 1991, 29(7):13237.

20. Garcia LS, Brewer TC, and Bruckner DA. Fluorescence detection of Cryptosporidium oocysts in human fecal specimens by using monoclonal antibodies. Journal of clinical microbiology, 1987, 25(1):119-21.

21. Xiao L, Herd RP. Quantitation of Giardia cysts and Cryptosporidium oocysts in fecal sample by direct immunofluorescence assay. Journal of clinical microbiology, 1993, 31(11):2944-6.

22. Alles AJ et al. Prospective comparison of direct immunofluorescence and conventional staining methods for detection of Giardia and Cryptosporidium spp. in human fecal specimens. Journal of clinical microbiology, 1995, 33(6):1632-4.

23. Korich DJ et al. Effects of ozone, chlorine and monochloromine on Cryptosporidium parvum oocyst viability. Applied and environmental microbiology, 1990, 56:1423-8.

24. Casemore DP, Wright SE, Coop RL. Cryptosporidiosis-human and animal epidemiology. In: Fayer R, ed. Cryptosporidium and cryptosporidiosis. Boca Raton, Florida, CRC Press, 1997.

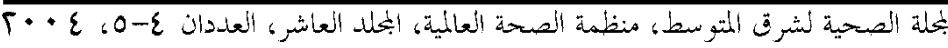

